https://doi.org/10.15407/scine16.03.092

\author{
KRAUS, N.M. ${ }^{1}$, KRAUS, K.M. ${ }^{1}$, and ANDRUSIAK, N.O. ${ }^{2}$ \\ 'Borys Grinchenko Kyiv University, \\ 18/2, Bulvarno-Kudriavska St., Kyiv, 04053, Ukraine, \\ +380 44272 1902, kubg@kubg.edu.ua \\ ${ }^{2}$ Bohdan Khmelnytsky National University of Cherkasy, \\ 81 , Shevchenko Blvd., Cherkasy, 18031, Ukraine, \\ +380 472372142 , cic@icdu.edu.ua
}

\title{
DIGITAL CUBIC SPACE AS A NEW ECONOMIC AUGMENTED REALITY
}

Introduction. Digital cubic space implies the formation of new economic augmented reality into socio-economic life at various levels of economic aggregation, thus accelerating the digitalization of Ukrainian economy.

Problem Statement. Taking into account the existing REFD developments in the field of knowledge of digital economy, not yet learned is transformation of digital technologies at the enterprise, based on the introduction of innovative changes such as BlockChain, FinTech, front office, back office, middle office, omni-business.

Purpose. Disclosure of the content of digital cubic space as a new economic complemented reality and presentation of its characteristics through the knowledge of qualitative functioning of FinTech's and the peculiarities of BlockChain, the formation of which occurs during the digitization of the economy, for the purpose of creation of digital products/services.

Materials and methods. Based on the dialectic, system and matrix methods, digital cubic space becoming a new supplemented reality during the digitization of Ukrainian economy has been studied. A comparison of innovative development ratings that affects the speed of digitalization in individual countries around the world has been used.

Results. By analogy with the construction of well-known Rubik's cube, author's proved that the formation of an efficiently functioning digital economy is possible in conditions of simultaneous harmonic relations "sciencebusiness-government-education" resulting in a special environment - digital cubic space of new economic augmented reality. The FinTech 1.0, FinTech 2.0, FinTech 3.0, FinTech 3.5 technologies have been distinguished. The author's interpretation of the content of digital economy and the category "digital cubic space" has been proposed. The distinction between virtual, extended, expanded, improved, enriched, mixed realities is indicated.

Conclusions. Digital cubic space forms a new economic augmented reality at the expense of digital discoveries, the volume of the market of digital products/services. Such institutions are included in the driving forces of digital cubic space: digital hubs, digital platforms, digital currency, FinTech, RegTech, SupTech, new industrial technology Industry 4.0.

Keywords: virtual reality, digital cubic space, FinTech, augmented reality, digital services portals, and BlockChain.

Citation: Kraus, N.M., Kraus, K.M., and Andrusiak, N.O. Digital Cubic Space as a New Economic Augmented Reality. Sci. innov. 2020. V. 16 no. 3. P. 92-105. https://doi.org/10.15407/scine16.03.092 
Recent changes in the economy and society have caused adequate changes in the world economy. Today's economic concepts and categories are replaced by new ones, which can be generalized as the emergence of a new economy. This digital economy has its specific definitions, laws, models of world development, economic development as a science and as an industry that gains pace in history [1]. In the $21^{\text {st }}$ century, the interest of researchers and economists to digital transformation has significantly increased in economic research. After all, digitalization provides real opportunities for economic growth.

There is a wide space for innovation activities of corporations in all sectors of the economy to be implemented through dialogue with the government, intersectoral cooperation and joint development of large projects on the basis of "deep" digitalization. In the last two years, the global hype about the Blockchain technology and cryptocurrencies has not abated, and the financial regulators of the most advanced economies hardly keep up in responding to new challenges. The high-speed mobile Internet has caught the world in its "invisible web", expanding the banking market and challenging conventional approaches. The extensive use of sensors, distance learning and Big Data have been changing the paradigm of risk assessment and assets management. Organizations are getting "unmanned", which minimizes staff costs and speeds up the service process. In addition, we shall keep in mind that the digital economy has been radically changing the nature of labor and remuneration. If our planet became deenergized, the world would plunge into universal madness and global chaos. We have got used to technology so badly that can refrain from eating rather than from reading messages on the screen of a mobile phone. Mankind has adapted and learned to live with technology, fully digitizing our way of life.

Foreign researchers R. Azuma [2], W. Isaacson [3], P. Milgram, F. Kishino [4] have studied the general aspects of structural reforms and complex modernization of the economy towards digitali- zation. Well-known economists G. Androschuk, Yu. Bazhal, O. Bilorus [5], O. Vietska, V. Vyshnevskyi [6], O. Vyshnevskyi [7], N. Vasylenko [8], V. Heyets, O. Garkushenko [6], V. Groisman [9], Ya. Zhalilo, N. Yegorov [10], S. Koliadenko [1], S. Kniazev [6], V. Kupriyanskyi [11; 20], S. Kubiv [13], P. Leonenko [14], V. Liashenko [7], O. Liakh [6], B. Paton [15], S. Pakhomov, A. Poruchnik, S. Syniagov [12], A. Sukhomlin [16], V. Chekina, D. Cherevatskyi [6] and others have dealt with the formation of virtual reality and augmented reality in the national economy, digital modernization of Ukraine's economy as opportunity for its disruptive development and with the study of prospects, directions, and mechanisms of the development of smart industry in the digital era. S. Bespalov, G. Golotsukov, V. Ivlichev, S. Ivanov, M. Pustovoit, I. Malchevskyi, D. Nikolenko, V. Kirsanov, O. Khimich, and I. Shchetynin have been involved in the development and implementation of distributed information technologies related to the processing of documents related to opening, execution, control, accounting, and closure of research and development works [17]. However, many problems, such as the formation of digital business platforms in Ukraine and high-quality information virtual and augmented reality of the national innovation space within the global digital space have remained understudied.

The purpose is to disclose the content of digital cubic space as a new economic augmented reality and to present its general characteristics through the knowledge of peculiarities of the application of some new technologies that are formed in the course of economy digitalization resulting in the creation of digital products/services and various platforms. The objectives are: to disclose, in a well-argued manner, the content of a special environment proposed by the authors, the digital cubic space of new economic augmented reality, similarly to the well-known "Magic Cube" designed by Hungarian sculptor Erno Rubik; to offer the authors' vision of its structural elements as a new augmented and virtual socio-economic 
reality; to study the taxonomy and categorization of terminology with which it is possible to establish the formation of the digital economy and its further development; based on the introduction of innovative changes to show a gradual transformation of digital technologies by a corporation in terms of such stages as: front office back office, middle office, and omni business; using the matrix method, to distinguish FinTech 1.0, FinTech 2.0, FinTech 3.0, and FinTech 3.5 with indication of their key elements and to define the structure of the FinTech market.

Today, within the post-nonclassical discourse, the practice of postmodernism as an epistemological concept of real space research is transformed into a meta-modern paradigm based on cognition and creation, in the economic context, of virtual economy and its basic component, financonomics, the space of financial relations, that is more and more evidently separated from the real sector economy into a specific area of research [15]. The digital economy is the result of transformational processes of the general-purpose state-of-the-art technologies in the field of information and communication, the formation of which testifies to a new level of the use of information and communication technologies in all areas of socio-economic activity. Robotics, artificial intelligence, cloud technology, 3D printers, and BlockChain have been already come into general use. Smart cities, courier drones, and driverless cars "printed" in one day at home are our tomorrow reality. Fantasy novels have come true. Technological progress has conquered the world of business and forced all industries to change.

In the $21^{\text {st }}$ century, such a categorical apparatus as "virtual reality" and "augmented reality" has deeply rooted into economic and engineering academic literature. The terms "expanded reality", "improved reality”, "enriched reality" are sometimes used as synonyms.

The term "augmented reality" is used to describe all projects aiming at supplementing the reality with any virtual elements. Augmented reality is an integral part of mixed reality that also includes "augmented virtuality" (when real objects are integrated into a virtual environment) [18]. There are several definitions of augmented reality. In 1997, Ronald Azuma [2] identified augmented reality as a system that combines the virtual and the real things; interacts in real time; operates in 3D. Paul Milgram and Fumio Kishino give a slightly different interpretation. They interpret virtual reality as a space between reality and virtuality, between which there are augmented reality (closer to reality) and augmented virtuality (closer to virtuality).

We believe that virtual reality of the multiuser world is based on the exchange of virtual goods within the on-line environment. It creates an opportunity to interact with the artificial world through virtual platforms with available information funds of on-line innovation market and to work with cloud technologies. We use augmented reality as a contactless information interaction that gives an illusion of direct entry and real-time presence in a stereoscopically represented "digital world" with the help of complex multimedia operating environments. We interpret "enriched reality" as a digital space created by computer technology, which has all hallmarks of reality as one that can be penetrated and transformed through globality and interactivity. "Improved reality" means a reality that is modeled in real time due to the impact of a computer on human consciousness (for example, a person wears "electronic gloves"). "Extended reality" can interact with all other realities, affect the world around us and have feedback. Augmented reality as a component of mixed reality is a combination of virtual and real spaces through hardware and software, telecommunications, computer networks, and shapes the digital economy.

Digital economy is a system of relationships in the field of production, sales, and supply of products through computer networks, using digital technology. Digital economy is an economy in which the key factors (means) of production are digital data and their use, which enables a significant increase in efficiency/productivity in va- 
rious economic activities. Noteworthy is the definition of digital economy as the possibility of creating a measurable real world or its digital model that with the introduction of new dimensions, in addition to the three-dimensional physical world, creates opportunities to account the features of the real environment, which were inaccessible before and both physical and business processes that take place in it [16].

Speeding up the digitalization in Ukraine and forming the digital economy are closely linked to the innovation development of the country. In April 2018, during a meeting with representatives of leading IT companies in Ukraine at that time, the Prime Minister of Ukraine V. Groysman noted that the IT industry was among the top three industries with the largest share in GDP. The IT products accounted for more than $3 \%$ of GDP; in 2017, the total revenue of the industry reached 3.6 billion dollars; so, in terms of revenue, the IT was the third behind agriculture and metallurgy. Today, more than 120,000 employees have been involved in this industry, the industry grew by $20 \%$ as compared with the previous year. There is every reason to believe that a significant potential of Ukraine's IT sector can be the basis for rapid development of the country's digital society. Table 1 shows the real status of digitalization of individual countries and Ukraine.

According to the above data, there is a high correlation between some indicators of the innovation development of advanced economies and Ukraine. As one can see, the leaders in innovation development are Switzerland, Sweden, Japan, Finland, Singapore, and USA. Ukraine's indicators are at the secondary level, although in 2018 , as compared with 2010 , there was a trend towards improving the rating.

Global innovation centers in Silicon Valley, New York, and London continue to accumulate global

Table 1. Comparison of Innovation Development Indicators That Influence Speedup of Digitalization in Individual Countries, in 2010 and in 2017-2018*

\begin{tabular}{|c|c|c|c|c|c|c|}
\hline \multirow{2}{*}{ Country } & \multicolumn{2}{|c|}{$\begin{array}{l}\text { Availability of cutting-edge } \\
\text { technologies * }\end{array}$} & \multicolumn{2}{|c|}{$\begin{array}{l}\text { Innovation as a key factor of } \\
\text { competitive ability * }\end{array}$} & \multirow{2}{*}{$\begin{array}{c}\begin{array}{c}\text { Ability to retain } \\
\text { talents * }\end{array} \\
2017-2018\end{array}$} & \multirow{2}{*}{$\begin{array}{c}\text { Internet users, \% } \\
2017-2018\end{array}$} \\
\hline & 2010 & $2017-2018$ & 2010 & $2017-2018$ & & \\
\hline Switzerland & 6.7 & 6.5 & 5.8 & 5.86 & 6.0 & 89.4 \\
\hline Sweden & 6.9 & 6.5 & 5.8 & 5.57 & 4.9 & 91.5 \\
\hline Japan & 6.3 & 6.3 & 5.7 & 5.55 & 3.9 & 92.0 \\
\hline Germany & 6.2 & 6.1 & 5.5 & 5.65 & 5.1 & 89.6 \\
\hline USA & 6.3 & 6.5 & 5.5 & 5.80 & 5.7 & 76.2 \\
\hline Great Britain & 6.5 & 6.3 & 5.2 & 5.34 & 5.3 & 94.8 \\
\hline Canada & 6.3 & 6.1 & 5.0 & 4.82 & 5.0 & 89.8 \\
\hline France & 6.4 & 6.0 & 4.9 & 5.07 & 3.3 & 85.6 \\
\hline India & 5.5 & 4.7 & 3.9 & 4.29 & 4.6 & 29.5 \\
\hline Russian Federation & .. & 4.4 & 3.24 & 3.76 & 3.5 & 76.4 \\
\hline Kazakhstan & 4.4 & 4.1 & 3.04 & 3.39 & 3.2 & 76.8 \\
\hline Ukraine & 4.6 & 4.1 & 3.29 & 3.55 & 2.2 & 52.5 \\
\hline
\end{tabular}

* Scored based on 7-point scale.

Note. Prepared by the authors based on [19]. 
venture capital, talents, and innovative corporations of the planet. Countries and cities, which focus on innovation development, create exclusive conditions for the introduction of start-up ecosystems. Corporations have been shifting to open innovation platforms, learning to develop new solutions involving the society of global talent. Foreign investors more and more often choose target teams with creative ideas and support potential opportunities instead of detailed business plans.

The experience of Switzerland, Germany, Canada, Finland, and Great Britain has shown that digital economy is characterized by much faster return on investment in specific projects and a higher profitability of individual projects [12].

The models of cloud services in the above mentioned countries include as follows:

- Infrastructure as a Service (IaaS) renders computing resources in the form of virtual resources with a given configuration, required quantities, and software;

- Platform as a Service (PaaS) provides a platform for developing, testing, deploying and supporting applications as services;

- Software as a Service (SaaS) involves the provision of software as a service [20].

Modern government agencies in different countries have focused on simultaneously improving the quality of services, optimizing the number of employees and reducing costs. "Digital" platforms (ERP, CRM) systems allow solving these problems and dramatically raising efficiency through reducing operating costs and execution time. Government agencies use "digital" platforms to simplify and to optimize internal processes, to improve communication with citizens, and to reduce costs [13]. The cost of access to infrastructure depends on both the level of income and the development of infrastructure, as well as on territorial specificity (mentality, traditions, norms of behavior, and prohibitions). Theoretically, the cost of access shows the balance between supply and demand in the Internet services market and varies consistently with changes in other indicators, but this is not always the case.
For successful development of Ukraine's digital economy, it is necessary to provide the following conditions: development of on-line services (services of social significance, public services); transition of government bodies and departments to digital technologies; development of the Internet of Things in the individual consumer sector (IoT) and in industry (IIoT); creation of domestic software, modern and promising information and telecommunication technologies to replace foreign products [20].

Ukraine 2030: the Doctrine of Balanced Development [21] states that for the national economy, large-scale adoption of new technologies can intensify the development of the services sector, reduce transaction costs (online financial services, delivery of goods by drones), increase overall efficiency and effectiveness in combating corruption (digital payment for administrative services), as well as improve access to education (online courses). The Doctrine assumes the following areas of digital development are important for Ukraine: additive technologies, new nano- and biomaterials, renewable energy, highly automated production; robotics (technology of artificial intelligence and intelligent systems); IT development (cloud technologies, mobile communication, and new generation of laptops); humanization (genetic engineering, nano- and biopharmacology, synthetic biology); and the go green initiative (low-carbon waste-free production, ecosystem remediation, and pollution control).

Similar to the well-known "Magic Cube" designed by Hungarian sculptor Erno Rubik [22], it can be stated that the formation of an effective digital economy is possible provided there are achieved simultaneous harmonious relations "science - business", "government - science", "government - business", "education - science", "education - government", "education - business" (obtainment of cube faces of the same color). As a result, a special environment - digital cubic space of the new economic augmented reality - is formed (Fig. 1). It gives innovative opportunities for communications, exchange of knowledge, ideas, and 


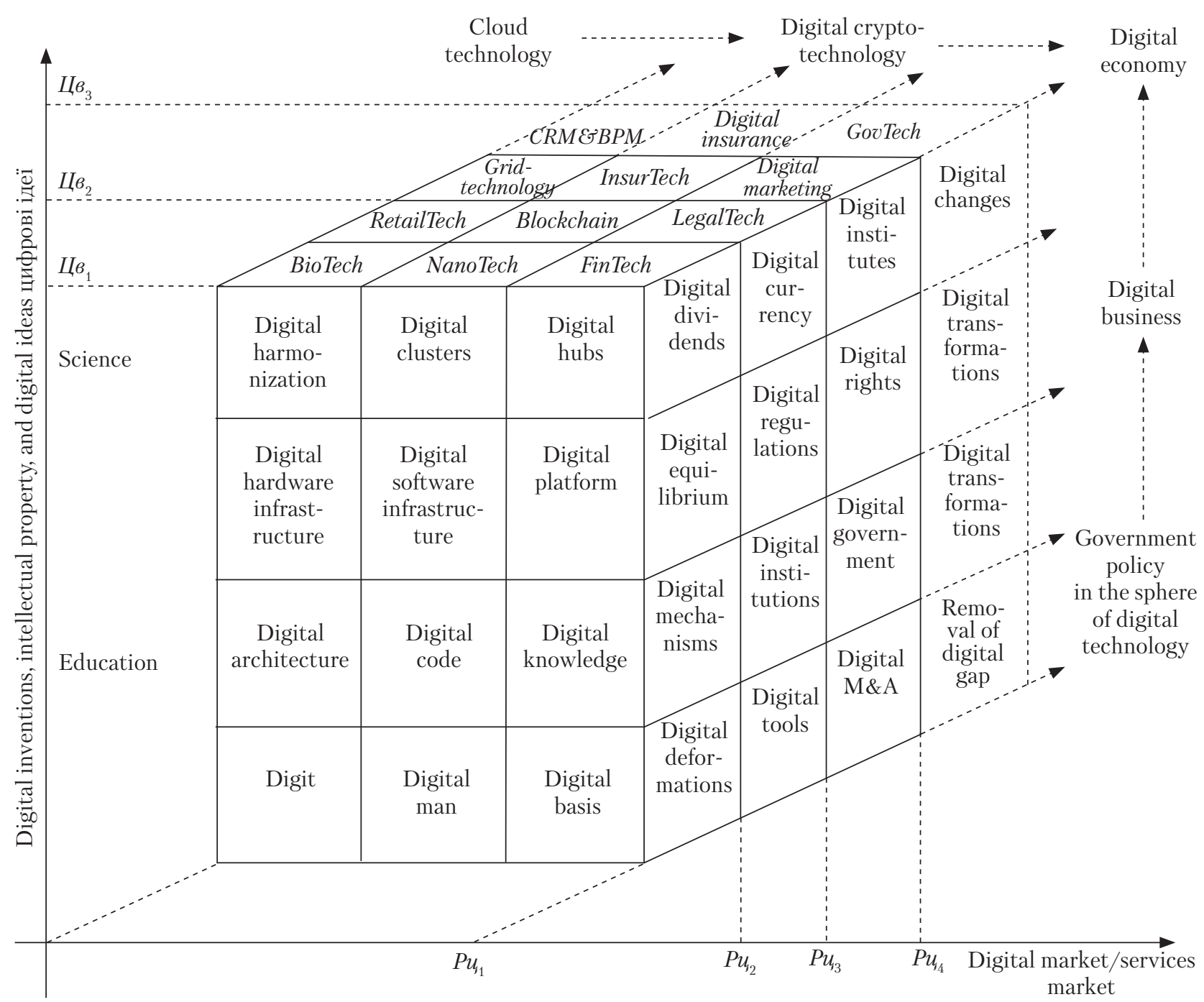

Fig. 1. Digital cubic space that forms new economic augmented reality: $P u_{1}$ is the reference point of the status of digital products/services market before the appearance of disruptive technologies used in education, business, and governance; $P u_{1}$, $\mathrm{Pu}_{3}, \mathrm{Pu}_{4}$ are the points of variations in the status of digital products/services market, as a result of implementation of critical digital and cloud technologies; $\left\lfloor\theta_{1}\right.$ is the initial number of patented discoveries, inventions, and ideas $\left\lfloor\theta_{2}, Ц \varepsilon_{3}-\right.$ are the increased numbers of digital discoveries, inventions, and ideas in various industries

Note. Developed by the authors.

experience between government, universities, and business through the use of digital computer technology in real time, space, and laws of existence.

On the horizontal axis (Fig. 1), point $P_{u 1}$ denotes the initial state of the digital products / services market before the implementation of the latest technologies in education, business, and government, and points $P_{u 2}, P_{u 3}, P_{u 4}$ show changes in the status of the digital products / services market as a result of implementation of critical digital and cloud technologies. On the vertical axis, point $Ц_{B 1}$ corresponds to the initial number of inventions, discoveries, and patented ideas, and points $Ц_{62}$,

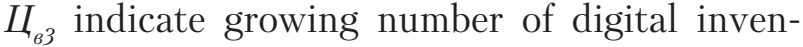
tions, discoveries, and ideas in various industries.

Speedup of digitalization of Ukraine's economy is possible through an effectively functioning digital cubic space that implies the integrated use 
of software and IT solutions to make learning (education) more qualitative and interesting, city life more comfortable, doing business and to advance to a new level of interaction between the community and the government. The digital cubic space of the new economic augmented reality is a way of development, progress, and transition to a new level of civilization rather than a trend.

Table 2. Some Cutting-Edge Technologies that Define the Formation of Digital Economy

\begin{tabular}{|c|c|}
\hline Advanced technology type & Content and specific features of advanced economy \\
\hline $\begin{array}{l}\text { BlockChain } \\
\text { technologies }\end{array}$ & $\begin{array}{l}\text { Form a new space of trust for digitization of large databases (cadasters, property registers, etc.) } \\
\text { BlockChain technology is a digitized, decentralized event register that operates online within a } \\
\text { single network of nodes (e.g., computers) and is constantly updated with new blocks (events, } \\
\text { transactions) in chronological order without centralized accounting. With regard to BlockChain- } \\
\text { platforms, the key unresolved issue is personal responsibility or collective irresponsibility. } \\
\text { The use of BlockChain enables transition to a new model of "shared" economy that prevents the } \\
\text { monopolization of certain market segments, like in the case of Uber (which is an aggregator of } \\
\text { information). Thus, we can predict escalating competition between the existing digital platforms } \\
\text { and the BlockChain platforms. }\end{array}$ \\
\hline RegTech & $\begin{array}{l}\text { Special regulatory technology that helps financial institutions meet regulatory requirements by } \\
\text { data verification and protection, automation of reporting. RegTech provides companies with the } \\
\text { necessary tools to address regulatory issues and to comply with legal requirements, bringing to- } \\
\text { gether the commercial, fiscal, and financial regulations. } \\
\text { RegTech technologies help to quickly and easily integrate and to adapt ready-made solutions for } \\
\text { full compliance with all standards of financial regulators and are used to combat money launder- } \\
\text { ing. Financial institutions are increasingly interested in RegTech, as it gives a competitive advan- } \\
\text { tage and allows them to generate and submit reports, to identify and eliminate risks, to effec- } \\
\text { tively comply with ever-changing regulatory requirements. }\end{array}$ \\
\hline SupTech & $\begin{array}{l}\text { SupTech is a supervision technology, a variant of RegTech technology for financial regulators that } \\
\text { allows users to automate and to optimize administrative and operational procedures, to digitize } \\
\text { data and working tools, and to improve data analytics. }\end{array}$ \\
\hline FinTech & $\begin{array}{l}\text { The benefits of FinTech for financial institutions are reduced transaction costs for finding and } \\
\text { attracting customers; technological solution to the problem of information asymmetry while in- } \\
\text { teracting with customers and with financial markets in general, which was previously solved by } \\
\text { rationing methods (although FinTech does not exclude this approach). The benefits for customers } \\
\text { are getting the products they really need, without any additional fees and unnecessary payments } \\
\text { that increase the real interest rate; round-the-clock access to financial resources } 7 \text { days a week } \\
\text { and } 365 \text { days a year. This is especially important for smart companies that implement the prin- } \\
\text { ciples of digitized customer-oriented work. The main disadvantage of FinTech companies is the } \\
\text { limited use of their services today. }\end{array}$ \\
\hline WealthTech & Technology for managing personal funds and well-being of an economic entity or an individual. \\
\hline $\begin{array}{l}\text { Advanced industrial tech- } \\
\text { nologies of Industry } 4.0- \\
\text { cyber-physical systems } \\
(C P S)\end{array}$ & $\begin{array}{l}\text { 3D-technologies (printing), genetic engineering, customized pharmacy, Internet of Things, crea- } \\
\text { tion of a quantum processor. This list of cutting-edge technologies that radically change produc- } \\
\text { tion in the near future may be extended. }\end{array}$ \\
\hline $\begin{array}{l}\text { Neurocomputer } \\
\text { interface }\end{array}$ & $\begin{array}{l}\text { Brain-computer technology is the control of objects through commands directly from the brain, } \\
\text { robotics, artificial intelligence.. }\end{array}$ \\
\hline Biotechnology & Genetic engineering, organ and tissue engineering, creation of prostheses and artificial organs. \\
\hline Biometrics & $\begin{array}{l}\text { The technology involves digital capture and storage of unique characteristics of customers (e.g., } \\
\text { fingerprints, retina, voice, facial features) primarily to enhance the security (and convenience) of } \\
\text { financial transactions. }\end{array}$ \\
\hline
\end{tabular}

Note. Prepared by the authors based on $[23 ; 6 ; 7]$ and their own research. 
This space contributes in every way to the creation and distribution of digital goods / services. At the same time, science and education act as generators of knowledge, innovative ideas, and digital initiatives, the owner of intellectual property in the commercialization of which both government (government support in the form of digitalization policy) and business (profit through Institute of Digital Market) are interested and actively involved. It should be noted that for the full operation of the digital environment, education requires systematic efforts on the stable functioning of the digital system in the regions, based on effective interaction of major participants in digitalization and digital business aiming at creating new business lines.

The digital infrastructure (Fig. 1) provides the necessary conditions for the implementation and operation of smart innovations. The main components of the digital infrastructure are applications (services, application software, data management); data centers (servers, data storage centers, data processing centers, redundancy); information and communication networks (Internet, broadband networks, sensor networks, data networks, Wi-Fi); and information collection systems (sensors, gadgets, smart video surveillance systems, terminals). The "soft" and "hard" digital infrastructure and electronic business operations are connected by means of hardware, software, and telecommunications.

We believe, in the digital cubic space, it is necessary to focus on the latest BlockChain technology as basis for the economy digitalization. BlockChain is a critical digital technology that is the basis of digital products / services, such as: BioTech, NanoTech, RetailTech, FinTech, LegalTech, Digital-marketing, Grid-technologies, GovTech, e-ID, TeleHealth, ePrescription, e-democracy, and Digital insurance. The content and specific features of the cutting-edge technology that form a digital cubic space are given in Table 2. The digital products/services, their types and forms are presented in Table 3.

\section{Table 3. Digital Products/Services and Platforms Created in the Course of Economy Digitalization}

\begin{tabular}{|c|c|}
\hline Advanced technology type & Content and specific features of advanced economy \\
\hline Digital platforms & $\begin{array}{l}\text { In the context of the key principles of digital economy, digital platforms are based on IT } \\
\text { infrastructure, on the one hand, and are the basis for not only e-commerce and e-business, } \\
\text { but also for the whole range of communications in the triangle "business - consumers - } \\
\text { government", on the other hand. The digital procurement platform provides the following } \\
\text { benefits for the customers: } \\
\text { maximization of the number of suppliers and the possibility of their expansion without } \\
\text { increasing the cost of attracting them; } \\
\text { optimization (minimization) of procurement costs; } \\
\text { automated selection of supplier; } \\
\text { reduction of corruption risks. } \\
\text { The digital platform is a convenient place for the formation of digital barter when digital } \\
\text { values unaccounted by national statistical services and fiscal authorities are exchanged. } \\
\text { This creates problems for the formation of a fair system for meeting public needs through } \\
\text { tax revenues. }\end{array}$ \\
\hline $\begin{array}{l}\text { Platform companies as basic } \\
\text { link of new economy }\end{array}$ & $\begin{array}{l}\text { Platform is a technological capability for value proposition to customers, based on the use of } \\
\text { open source solutions, machine learning, and cloud technologies with required security level. }\end{array}$ \\
\hline Digital education platform & $\begin{array}{l}\text { Allows employers to search potential candidates and to check the quality of their training } \\
\text { online. Also, the digital educational platform can act as a crowdfunding platform for busi- } \\
\text { ness co-financing of promising areas of education. Using BlockChain technology enables } \\
\text { automatic transfer of certain cryptocurrencies to the authors of training courses, depending } \\
\text { on the number of students who have completed the training. Students can automatically } \\
\text { receive certificates or diplomas subject to the requirements of smart-contracts. }\end{array}$ \\
\hline
\end{tabular}




\begin{tabular}{|c|c|}
\hline Advanced technology type & Content and specific features of advanced economy \\
\hline $\begin{array}{l}\text { Digitalization of medical ser- } \\
\text { vices on eHealth platform } \\
\text { (National electronic health- } \\
\text { care system) }\end{array}$ & $\begin{array}{l}\text { Introduction of BlockChain technology while forming a personal electronic medical card; } \\
\text { equipping the eHealth system with rating tools from licensed healthcare facilities, doctors, } \\
\text { and pharmacies; patient register (does not contain medical information); register of health- } \\
\text { care entities of any form of ownership (including private offices, self-employed, LLCs, etc.), } \\
\text { which provide medical care at the primary level of the healthcare system; register of medical } \\
\text { officers who provide primary healthcare (mainly, doctors); register of contracts and agree- } \\
\text { ments between healthcare institutions and the National Health Service of Ukraine, between } \\
\text { the primary care physician and the patient; register of medicines; register of prescriptions } \\
\text { for medicines reimbursable by the government. }\end{array}$ \\
\hline Neurocomputer interface & $\begin{array}{l}\text { "Brain - computer" technologies enable control of objects through commands directly } \\
\text { from the brain, robotics, artificial intelligence. }\end{array}$ \\
\hline $\begin{array}{l}\text { (Application Program Inter- } \\
\text { face }(A P I)\end{array}$ & $\begin{array}{l}\text { A set of ready-made protocols, functions, and structures, which determine the interaction of } \\
\text { different programs. }\end{array}$ \\
\hline $\begin{array}{l}\text { Digital money (in particular, } \\
\text { cryptocurrencies) and new fi- } \\
\text { nancial instruments }\end{array}$ & $\begin{array}{l}\text { Money of this type will lead to radical changes in the financial market and speed up the in- } \\
\text { vestment processes. It differs from conventional currencies as not created or controlled by } \\
\text { any government. }\end{array}$ \\
\hline Cryptography & Protects information by converting it to a secure format (for example, by encryption). \\
\hline Smart contracts & $\begin{array}{l}\text { These are contracts that are executed automatically in the BlockChain environment, under } \\
\text { certain conditions. This type of contract enables direct exchange of values. At the same } \\
\text { time, there is an opportunity to simplify and increase reliability of realization of B2B and } \\
\text { B2G transactions. Digitizing information and combining it into systems (graphs) that com- } \\
\text { pete with each other is a new era in searching and accessing information. }\end{array}$ \\
\hline Artificial intelligence $(A I)$ & $\begin{array}{l}\text { Capabilities of computer programs to perform tasks such as problem solution, language rec- } \\
\text { ognition, visual perception, decision making and language translation. AI has many applica- } \\
\text { tions and is increasingly used in the financial sector (robotic consulting, transaction au- } \\
\text { thentication). }\end{array}$ \\
\hline $\begin{array}{l}\text { Internet-banking (e-banking, } \\
\text { або on-line Banking, або web- } \\
\text { banking) }\end{array}$ & $\begin{array}{l}\text { One of the types of remote banking, which provides access to accounts and transactions at } \\
\text { any time and from any computer via the Internet, using a standard browser, such as Google } \\
\text { Chrome, Internet Explorer, Opera, Mozilla etc. This technology enables bank customers to } \\
\text { manage their accounts by electronic means, via the Internet. }\end{array}$ \\
\hline Ecosystem & $\begin{array}{l}\text { Digital-organization based on a technology platform that allows real-time formation of the } \\
\text { best offer for client through connecting external providers, on the basis of big data. }\end{array}$ \\
\hline New logistics & Based on standard infrastructure solutions (Uber, car sharing, drones). \\
\hline
\end{tabular}

Note. Prepared by the authors based on $[6,7,23]$ and their own research..

The BlockChain-technology of a distributed peer-to-peer public network can store information about transactions on a permanent basis, without the possibility of its change, as it is protected by cryptographic means. BlockChain networks provide many options for various purposes, especially in the public sector (e-referendums, epetitions, e-voting, e-government, etc.). The advantage of this technology is that it ensures an unprecedented level of information protection and allows users to create fully decentralized systems. A high resistance of the system to attacks allows its use in such sensitive areas as e-finance, public procurement, e-budgets. A quarter of the world-class BlockChain projects has Ukrainian origin. Therefore, Ukraine is the territory where research into this technology shall continue and new developments shall be created. The public 
Table 4. FinTech Matrix Structure in Terms of Time, Key Elements, and FinTech Market Structure

\begin{tabular}{|c|c|c|c|c|}
\hline \multirow{2}{*}{$\begin{array}{c}\text { FinTech } \\
\text { evolution }\end{array}$} & \multicolumn{4}{|c|}{ Еволюція FinTech } \\
\hline & FinTech 1.0 & FinTech 2.0 & FinTech 3.0 & FinTech 3.5 \\
\hline $\begin{array}{l}\text { Territorial } \\
\text { allegiance }\end{array}$ & $\begin{array}{l}\text { Global economy, advan- } \\
\text { ced economies }\end{array}$ & $\begin{array}{l}\text { Global economy, post- } \\
\text { industrial countries }\end{array}$ & Postindustrial countries & $\begin{array}{l}\text { Developing countries / } \\
\text { Emerging markets }\end{array}$ \\
\hline Key elements & $\begin{array}{l}\text { Infrastructure, compute- } \\
\text { rization }\end{array}$ & $\begin{array}{l}\text { Conventional, innova- } \\
\text { tive, Internet }\end{array}$ & Mobile devices, Startups & Digital, new members \\
\hline Examples & $\begin{array}{l}\text { Transatlantic cable (1866), } \\
\text { telex (circuit-switched } \\
\text { network designed to send } \\
\text { and receive text messa- } \\
\text { ges, conceptually similar } \\
\text { to a telephone network, } \\
\text { but with teletypes as sub- } \\
\text { scriber devices (1966) }\end{array}$ & $\begin{array}{l}\text { First ATM (1967), } \\
\text { SWIFT (1973), On- } \\
\text { line banking (1983- } \\
\text { 1985) Internet / Dot. } \\
\text { Com- bubble (1999) }\end{array}$ & $\begin{array}{l}\text { iPhone (2007), BitCoin } \\
(2009)\end{array}$ & $\begin{array}{l}\text { MyBank, WeBank (2015) } \\
\text { Chinese online banks wit- } \\
\text { hout phys-ical outlets }\end{array}$ \\
\hline Changes & $\begin{array}{l}\text { Communications, interac- } \\
\text { tions, interdependencies }\end{array}$ & Innovatization & $\begin{array}{l}\text { Financial crisis 2008, smart- } \\
\text { phones, iPad, netbook, mo- } \\
\text { bile Internet devices }\end{array}$ & $\begin{array}{l}\text { Digitalization, mobility ad- } \\
\text { vantages, tablets, ultrabooks }\end{array}$ \\
\hline
\end{tabular}

Note. Prepared by the authors based on $[6,7,13,14,23,24]$ and their own research.

sector and the national institutional environment shall create the most optimal, efficient, transparent, and high-quality conditions for implementing such projects [13].

The evolution of FinTech development, its key elements, the structure of the FinTech market by types of companies have been successfully demonstrated by the authors using the matrix method (Table 4).
Thus, the digital economy based on networkcluster structures for interaction of all involved in digitalization, within the digital cubic space model, can be one of effective tools on the way towards the innovation-driven digital economy in Ukraine. With targeted government support of digital development institutions, it is possible to achieve the widespread use of modern scientific technologies in production processes for the ma- 
Table 5. Gradual Transformation of Digital Technologies Based on Disruptive Changes

\begin{tabular}{|c|c|c|c|}
\hline Stage of transformation & Step-by-step description & $\begin{array}{l}\text { General ideas of gradual } \\
\text { transformation of digital } \\
\text { technologies }\end{array}$ & $\begin{array}{l}\text { Specific features of transformation of } \\
\text { digital technologies }\end{array}$ \\
\hline $\begin{array}{l}1^{\text {st }} \text { wave transforma- } \\
\text { tion }(2000-2010)\end{array}$ & $\begin{array}{l}\text { Front office: } \\
\quad \text { 1. Mobile technologies } \\
\text { 2. Digital marketing } \\
\text { 3. Digital engagement of } \\
\text { customers }\end{array}$ & $\begin{array}{l}\text { Front office is a group of depart- } \\
\text { ments or processes in the orga- } \\
\text { nization, which are responsible } \\
\text { for direct servicing of clients/ } \\
\text { customers }\end{array}$ & $\begin{array}{l}\text { 1. The activity focused on the front } \\
\text { office and the quality of customer } \\
\text { service. } \\
\text { 2. Organizations sought digital op- } \\
\text { portunities through strategic ac- } \\
\text { quisitions (e.g., startups). } \\
\text { 3. Startups entered the market and } \\
\text { played a significant role. }\end{array}$ \\
\hline \multirow[t]{2}{*}{$\begin{array}{l}2^{\text {nd }} \text { wave transforma- } \\
\text { tion 9expected in } \\
2020)\end{array}$} & $\begin{array}{l}\text { Back office: } \\
\text { 1. Digital transformation } \\
\text { of corporation } \\
\text { 2. Digital supply channel } \\
\text { Middle office: } \\
\text { 1. Leading business mod- } \\
\text { els } \\
\text { 2. Digital business strate- } \\
\text { gy }\end{array}$ & $\begin{array}{l}\text { Back office is an organization } \\
\text { unit that conducts business pro- } \\
\text { cesses, increases productivity } \\
\text { by optimizing workflows and } \\
\text { eliminating inefficient manual } \\
\text { operations throughout the life- } \\
\text { cycle of business processes. } \\
\text { Middle office is a group of divi- } \\
\text { sions or processes, which is re- } \\
\text { sponsible for risk management, } \\
\text { estimate of profits and losses } \\
\text { and for IT development. The } \\
\text { middle office attracts resources } \\
\text { from both the front and the back } \\
\text { offices. }\end{array}$ & $\begin{array}{l}\text { 1. Digital focus only at the front of } \\
\text { fice does not provide a competitive } \\
\text { advantage. } \\
\text { 2. In order to implement a full-scale } \\
\text { digital transformation, organiza- } \\
\text { tions are required to focus on re- } \\
\text { structuring operations that go be- } \\
\text { yond customer service. } \\
\text { 3. Organizations will spend more } \\
\text { on digital technology in the middle } \\
\text { office and back office than in the } \\
\text { front office. }\end{array}$ \\
\hline & Omni-business & $\begin{array}{l}\text { Omni-business business is ap- } \\
\text { proach based on integrity and } \\
\text { consistency of user's experience }\end{array}$ & $\begin{array}{l}\text { Its main advantage is that users are } \\
\text { free to switch between information } \\
\text { channels, such as mobile device, } \\
\text { laptop, social networks and off-line } \\
\text { store. }\end{array}$ \\
\hline
\end{tabular}

Note. Developed by the authors.

nufacture of competitive products [10], thereby significantly increasing the share of digital services/products in the total gross domestic product.

Successful digital transformation programs mean the creation of successful processes, new products and services. To achieve the desired results in all areas of the economy and in the life cycles of corporations, products and services, it is necessary to expand the scope of rights and opportunities concentrated in the point where all the organization resources are strategically directed to work together in today's digital market [12]. It is also important to believe that this can be achieved through digital citizenship that is characterized by digital literacy interpreted as the ability to work with a large amount of information obtained from several sources; the ability to assess its reliability and usefulness using established criteria; the ability to solve problems that require skills for searching information related to an unfamiliar context, in the presence of ambiguity and without explicit instructions [16].

Convergence with an activated blockchain connection transforms the value chain. Autonomous robotics, AI, IoT, and BlockChain digitize logistics and distribution, reducing its importance and thus increasing the ability of corporations to make a profit. Manufacturers are able to get more value that they create, while consumers pay less. In long run, technical deflation will be in 


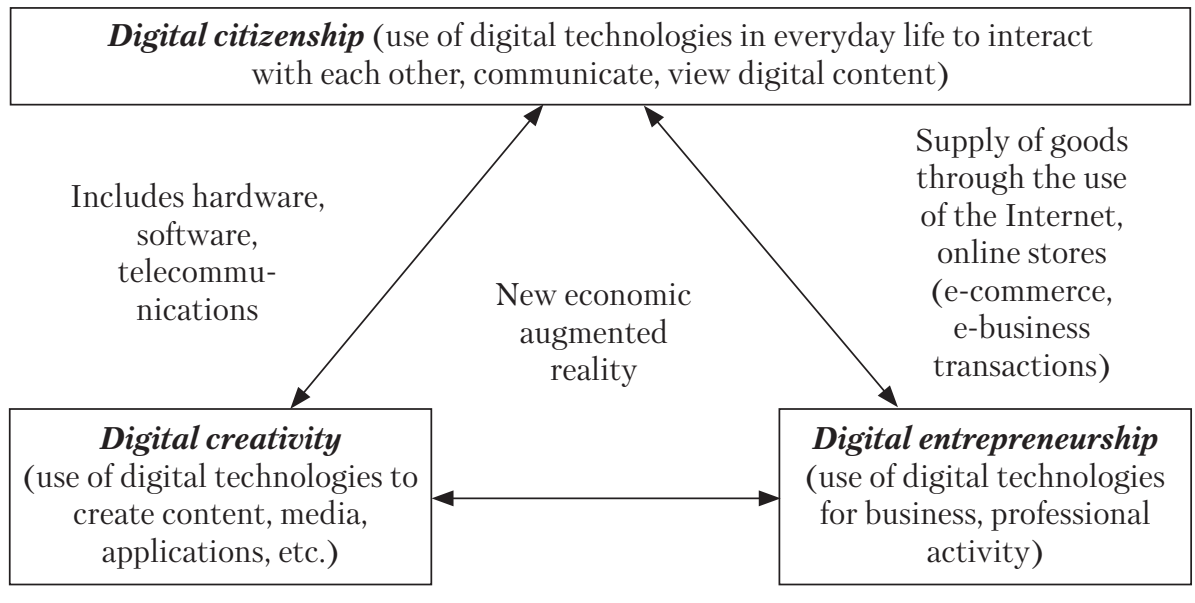

Involves business process implemented through computer networks within virtual interactionsbetween virtual market entities

Fig. 2. Expected result in the course of effective operation of the economy in the digital cubic space

Note. Prepared by the authors based on $[1,8,14]$.

the depth of exponential curve, as 3D printing, together with virtual and augmented realities, makes its design cheaper and allows printing products at home. It is a certain new technology that in the future will be determined by economic benefits [11]. The stages of transformation of digital technologies are shown in Table 5 .

While implementing the digital transformation model, it is necessary to take into account comprehensive adaptive capabilities that allow responding to inevitable changes. These capabilities provide the resources to involve all the structural strata in order to implement continuous improvement and innovation while forming digital entrepreneurship and make it possible to constantly adapt to changing customer needs and new opportunities in the global digital market [12]. The expected result of the effective operation of economy in the digital cubic space that forms a new economic augmented reality, is the formation of digital citizenship and digital entrepreneurship in Ukraine (Fig. 2).

Having a website gives corporation the following opportunities: customer service; online supply of products and services to customers; the ability of visitors to form orders for goods and ser- vices online and to monitor the status of orders; personalized information content of the website for loyal customers; links to the website in social media; announcement of job vacancies or application for vacancies online; staff training and acquisition of digital competencies.

Thus, the digital era of society is changing the approach to doing business, requires the use of information technology and modern means of communication. The use of ICT and the Internet by businesses to maximize the automation of business processes within corporation and to build relationships with other businesses, consumers, and government agencies through the use of advanced ICT is crucial for building digital economic relations.

As a result, it should be noted that the economy that uses digital technologies is called "digital economy", and the industry that creates, implements, and maintains them is named "digital industry". Digitalization and development of "digital" economy (antonym is "analog" economy) require titanic organizational and legislative efforts from the government, but success is impossible unless the government relies on the innovative and creative potential of domestic business and 
citizens [13]. The authors are deeply convinced that the digital cubic space of the economy of new augmented reality is the driving force of Ukraine's competitiveness, innovation, productivity, and swift economic growth in the global digital virtual and real environment.

Despite impressive scientific achievements of today, it is still important in the future to conduct research aiming at understanding the ideology of the shared economy, in order to form a digital reality in Ukraine. There is a need to find high-quali- ty tools for speeding up the digital development of Ukraine, as well as to focus attention on the development of high-quality and effective legislative and institutional opportunities for digitalization of the national economy. Further research is needed to find answers to the following questions: "What is the difference between an innovation system and an ecosystem?" "How to work in the ecosystem and with the innovation ecosystem?" "How can a corporation, city, and country influence and benefit from digital development of innovation?"

\section{REFERENCES}

1. Koliadenko, S. V. (2016, October). Joined at the hip: Theoretical aspects of digital economy as a science. Poster session presented at the VII International Scientific and Methodical Conference "Forum for Young Cyber Economists - Modeling of the Economy: Problems, Trends, Experience". Ternopil. [in Ukrainian].

2. Azuma, R. (1997). Joined at the hip: A survey of augmented reality presence. Teleoperators and Virtual Environments, 8, 355-385 [in English].

3. Aizekson, V. (2017). Innovators: as a group of hackers, geniuses and gurus, it has made a digital revolution. Kyiv: Our format.

4. Milgram, P., Kishino, A. F. (1994). Taxonomy of Mixed Reality Visual Displays. IEICE Transactions on Information and Systems, 12, 1321-1329.

5. Bilous, O. H. (2014). Global structural crisis and transformation of financial world-system. Finansy Ukrainy, 4, 32-46 [in Ukrainian].

6. Vyshnevskyi, V. P., Viietska, O. V., Harkushenko, O. M., Kniazev, S. I., Liakh, O. V., Chekina, V. D., Cherevatskyi, D. Ya. (2018). Smart industry in the era of digital economy: prospects, directions and mechanisms of development. Kyiv: Institute of Economics of Industrial Design [in Ukrainian].

7. Liashenko, V. I., Vyshnevskyi, O. S. (2018). Digital modernization of the Ukrainian economy as an opportunity for breakthrough development. UPL: http://hdr.undp.org/sites/default/files/reports/271/hdr_2011_en_complete.pdf (Last accessed: 12.01.2019) [in Ukrainian].

8. Vasylenko, N. V. (2017, May). Joined at the hip: Digital economy: concepts and reality. Poster session presented at the International Scientific and Practical Conference "Innovative Clusters in Digital Economy: Theory and Practice" (ВКАЗАТИ ДАТУ, Saint Petersburg), Saint Petersburg [in Russian].

9. Hroismam, V. The digital economy is capable of rapidly increasing GDP. Novyny ekonomiky. UPL: http://ua-ekonomist. com/16214-cifrova-ekonomka-zdatna-strmko-pdvischiti-vvp-groysman.html (Last accessed: 11.01.2019) [in Ukrainian].

10. Egorov, N. E. (2011). Conceptual framework for building a model of a regional innovation system based on the cluster approach. Innovation, 8(154), 89-91 [in Ukrainian].

11. Kupryianovskyi, V. P., Syniagov, S. A., Klymov, A. A., Petrov, A. V., Namyot, D. E. (2017). Digital supply chains and blockchain-based technologies in a collaborative economy. International Journal of Open Information Technologies, 5(8), 80-95 [in Ukrainian].

12. Kupryianovskyi, V. P., Dobrynin, A. P., Syniagov, S. A., Namyot, D. E. (2017). A coherent transformation model in digital economy - how to become digital leaders. International Journal of Open Information Technologies, 5(1), 26-33 [in Ukrainian].

13. Digital Advent of Ukraine 2020 ("Digital Agenda" - 2020). Conceptual basis (version 1.0). Priority areas, initiatives, projects of "digitalization" of Ukraine by 2020 (2016, December). HITECH office. UPL: https://ucci.org.ua/uploads/ files/58e78ee3c3922.pdf (Last accessed: 5.01.2019) [in Ukrainian].

14. Leonenko, P. M., Kraus, N. M. (2016). Financial support of innovation activity in Ukraine for technological developments. Finansy Ukrainy, 4, 50-64 [in Ukrainian].

15. Paton, B. Ye. (2016). National Paradigm of Sustainable Development of Ukraine. Kyiv: State institution "Institute of Natural Resources Economics and Sustainable Development of National Academy of Sciences of Ukraine" [in Ukrainian].

16. Kupryianovskyi, V. P., Sukhomlyn, V. A., Dobrynin, A. P., Raykov, A. N. (2017). Digital economy skills and education challenges. International Journal of Open Information Technologies, 5(1), 19-25 [in Ukrainian]. 
17. Khimich, O. M., Ivlichev, V. P., Malchevskyi, I. A., Bespalov, S. A., Pustovoit, M. M., Holotsukov, H. V., Shchetynin, I. Ye., Nikolenko, D. I., Ivanov, S. M., Kirsanov, V. F. (2018). Fundamentals of distributed information technology support for scientific and organizational activities of the National Academy of Sciences of Ukraine. Science and Innovation, 14(1), 53-66 [in Ukrainian].

18. Augmented reality. UPL: https://uk.wikipedia.org/wiki/Augmented reality (Last accessed: 15.11.2018) [in Ukrainian].

19. The Global Competitiveness Report 2017-2018: World Economic Forum (Ed. Professor Xavier Sala-i-Mart n). Columbia University Chief Advisor of The Global Competitiveness. Geneva. URL: http://www3.weforum.org/docs/GCR20172018/05FullReport/TheGlobalCompetitivenessReport2017\%E2\%80\%932018.pdf (Last accessed: 02.12.2018) [in Ukrainian].

20. Efimushkin, V. A., Ledovskikh, T. V., Shcherbakova, E. N. (2017). Infocommunication technological space of the digital economy. T-Comm: Telecommunications and transportation, 11(5), 15-20 [in Ukrainian].

21. Ukraine 2030: Doctrine of balanced development. (2017). Lviv: Kalvariia.

22. Rubik's Cube. UPL: https://uk.wikipedia.org/wiki/Rubik's Cube (Last accessed: 12.11.2018) [in Ukrainian].

23. FinTech, RegTech and SupTech: What They Mean for Financial Supervision. Toronto Leadership Centre. URL: http:// res.torontocentre.org/guidedocs/FinTech\%20RegTech\%20and\%20SupTech\%20\%20What\%20They\%20Mean\%20 for\%20Financial\%20Supervision.pdf (Last accessed: 12.01.2019).

24. Arner, D., Barberis, J., Ross P. (2015). The Evolution of Fintech: A New Post-Crisis Paradigm? University of Hong Kong Faculty of Law Research Paper. 2015/047, 1272-1319.

Received 15.01.19

Revised 07.02.19

Accepted 15.04.19

H.M. Краус ${ }^{1}$, K.M. Kраус ${ }^{1}$, H.O. Андрусяк ${ }^{2}$

${ }^{1}$ Київський університет імені Бориса Грінченка, вул. Бульварно-Кудрявська, 18/2, Київ, 04053, Україна,

+380 44272 1902, kubg@kubg.edu.ua

2 Черкаський національний університет імені Богдана Хмельницького, бульв. Шевченка, 81, Черкаси, 18031, Україна,

+380 47237 2142, cic@cdu.edu.ua

\section{ЦИФРОВИЙ КУБІЧНИЙ ПРОСТІР ЯК НОВА ЕКОНОМІЧНА ДОПОВНЕНА РЕАЛЬНІСТЬ}

Вступ. Цифровий кубічний простір передбачає формування нової економічної доповненої реальності в соціальноекономічне життя на різних рівнях економічної агрегації, тим самим прискорюючи цифровізацію економіки України.

Проблематика. Враховуючи існуючі наукові напрацювання у сфері пізнання цифрової економіки, невивченою $€$ трансформація цифрових технологій підприємством на основі впровадження інноваційних змін на зразок BlockChain, FinTech, фронт-офісу, бек-офісу, мідл-офісу, омні-бізнесу.

Мета. Розкриття змісту цифрового кубічного простору як нової економічної доповненої реальності та подання його характеристики через пізнання якісного функціонування FinTech і особливостей застосування BlockChain, становлення яких відбувається в ході цифровізації економіки, з метою створення цифрових продуктів/послуг.

Матеріали й методи. На основі діалектичного, системного та матричного методів досліджено цифровий кубічний простір, що стає новою доповненою реальністю при цифровізації економіки. Використано порівняння рейтингів інноваційного розвитку, що впливають на пришвидшення цифровізації в окремих країнах світу.

Результати. За аналогією побудови загальновідомого кубика Рубіка доведено, що формування ефективно працюючої цифрової економіки можливе за умов досягнення гармонійних взаємовідносин «наука-бізнес-влада-освіта», в результаті чого утворюється середовище - цифровий кубічний простір нової економічної доповненої реальності. Визначено відмінність між FinTech 1.0, FinTech 2.0, FinTech 3.0, FinTech 3.5. Запропоновано авторське осмислення змісту цифрової економіки та трактування категорії «цифровий кубічний простір». Вказано відмінність між віртуальною, доповненою, розширеною, поліпшеною та збагаченою реальностями.

Висновки. Цифровий кубічний простір формує нову економічну доповнену реальність за рахунок цифрових відкриттів, обсягу ринку цифрових продуктів/послуг. До рушійних сил цифрового кубічного простору належать такі інститути: цифрові хаби, цифрові платформи, FinTech, RegTech, SupTech, нові промислові технології індустрії 4.0.

Ключові слова: віртуальна реальність, цифровий кубічний простір, FinTech, доповнена реальність, портали цифрових послуг, BlockChain. 